\title{
Analisis perbaikan untuk mengurangi defect pada produk pelindung tangan dengan pendekatan lean six sigma
}

\author{
Antoni Yohanes ${ }^{1)^{*}}$, Firman Ardiansyah Ekoanindiyo ${ }^{2)}$ \\ ${ }^{12}$ Universitas Stikubank, Kendeng V Bendan Ngisor, Semarang, Indonesia. \\ antoni@edu.unisbank.ac.id*; firman@edu.unisbank.ac.id
}

\section{ABSTRAK}

CV. Cipta Manunggal Ungaran merupakan perusahaan manufaktur yang menghasilkan produk sarung tangan untuk olahraga golf dengan kapasitas produksi 35.000 pcs per bulan. Pada pembuatan produk belum terlepas dari proses produksi yang dapat menghasilkan produk cacat. Lean six sigma adalah suatu metode pendekatan sistemik dan sistematik untuk mengidentifikasi dan menghilangkan pemborosan atau aktivitas-aktivitas yang tidak bernilai tambah melalui peningkatan terus-menerus untuk mencapai tingkat kinerja enam sigma, dimana pada enam sigma tedapat 3,4 cacat dari satu juta peluang (DPMO - Defect Per Milion Opportunities). CV. Cipta Manunggal Ungaran baru mencapai nilai DPMO 3,9 maka masih harus berusaha mengurangi jumlah cacat. Hasil penelitian nilai DPMO 3,8 dan merekomendasikan kepada perusahaan perbaikan di bidang operator, metode kerja, bahan baku, mesin, lingkungan dan tata letak lantai produksi.

Kata kunci: Cacat;Lean six sigma;Perbaikan

\section{ABSTRACT}

\begin{abstract}
CV. Cipta Manunggal Ungaran is a manufacturing company that produces gloves for golf sports with a production capacity of 35,000 pcs per month. In the manufacture of products has not been separated from the production process that can produce defective products. Lean six sigma is a systematic and systematic approach method to identify and eliminate waste or non-value added activities through continuous improvement to achieve six sigma performance levels, where at six sigma there are 3.4 defects out of one million opportunities (DPMO - Defect Per Million Opportunities). CV. Cipta Manunggal Ungaran has only reached a DPMO value of 3.9, so it still has to try to reduce the number of defects. The results of the research have a DPMO value of 3.8 and recommend to companies for improvement in the fields of operators, work methods, raw materials, machines, environment and production floor layout.
\end{abstract}

Keywords: Defect;Lean six sigma;Repair

diunggah: Agustus 2021, direvisi: November 2021, diterima: Desember 2021, dipublikasi: Desember 2021

Copyright (c) 2021 Antoni Yohanes, Firman Ardiansyah Ekoanindiyo

This is an open access article under the CC-BY license

\section{PENDAHULUAN}

Bertahan diketatnya persaingan, salah satu permasalahan yang muncul yaitu kebutuhan perusahaan untuk menghasilkan produk berkualitas tinggi dengan penggunaan energi dan sumber daya yang tidak berlebih. Dalam proses menghasilkan produk yang berkualitas tidak lepas dari adanya produk cacat sehingga mengakibatkan kegagalan sebuah produk (defect product). Pengaruh produk cacat dapat berdampak pada biaya kualitas, image perusahaan, dan kepuasan pelanggan/konsumen. Semakin banyak produk cacat, semakin tinggi pula biaya kualitas dimana dapat memunculkan tindakan inspeksi, rework, dan sebagainnya. Untuk mengatasi permasalahan tersebut diperlukan sistem manajemen mutu atau pengendalian kualitas. 
Penelitian sebelumnya diantaranya Hamzah Asadullah Alkatiri (2015) melakukan penelitian dengan judul "Implementasi Pengendalian Kualitas Untuk Mengurangi Jumlah Produk Cacat Tekstil Kain Katun Menggunakan Metode Six sigma Pada PT. SSP" dengan hasil nilai rata-rata DPMO mengalami penurunan sebesar $1.769,47(27,13 \%)$ dan nilai sigma mengalami kenaikan sebesar 0,11 sigma $(2,76 \%)$.

Trismi Ristyowati (2017) dengan judul Minimasi Waste Pada Aktivitas Proses Produksi Dengan Konsep Lean Manufacturing (Studi Kasus di PT. Sport Glove Indonesia), Wahyu Adrianto (2015) dengan judul Analisis Penerapan Lean Production Process Untuk Mengurangi Lead Time Process Perawatan Engine (Studi Kasus PT.GMF Aerosia), Novia Alvin Nur Annisa (2014) dengan judul Pendekatan Lean six sigma Untuk Mengurangi Waste Proses Produksi Brown Paper (Studi Kasus: PT Kertas Leces, Kabupaten Probolinggo), Nailah, Ambar Harsono, Gita Permata Liansari (2014) dengan judul Usulan Perbaikan Untuk Mengurangi Jumlah Cacat pada Produk Sandal Eiger S-101 Lightspeed dengan Menggunakan Metode Six sigma.

Penelitian sebelum-sebelumnya menggunakan metode Lean six sigma sebagai metode yang tepat untuk mengetahui nilai sigma dari jumlah cacat yang terjadi sebagai tolak ukur mutu perusahaan dan 6 langkah perbaikannya untuk mengurangi jumlah cacat produk. CV.Cipta Manunggal Ungaran merupakan perusahaan manufaktur yang menghasilkan produk sarung tangan untuk olahraga golf dengan kapasitas produksi 35.000 pcs per bulan. CV. Cipta Manunggal memiliki target pemasaran ekspor, antara lain ke korea. Sistem produksi dan penjualan serta bahan bakunya yakni pre-order, dimana industri ini melakukan aktivitas produksi bila ada pesanan, namun antara buyer dan perusahaan ini telah melakukan $M O U$ atau perjanjian, sehingga terjadi aktivitas produksi barang secara continue sesuai dengan permintaan. Akan tetapi, pada pembuatan produk belum terlepas dari berbagai permasalahan mengingat adanya faktor-faktor pada proses produksi yang dapat menghasilkan produk tidak sesuai spesifikasi atau kegagalan produk (defect product). Kegagalan produk terjadi karena adanya cacat pada produk yang dihasilkan. Saat ini jumlah cacat produk yang terjadi cukup banyak. Maka untuk mengantisipasi terjadinya kegagalan produk sarung tangan golf perlu dilakukan pencarian penyebab-penyebab cacat pada produk yang kemudian dilakukan langkah peningkatan.

\section{METODE}

Penelitian terdahulu menjadi referensi dalam penelitian kali ini, diantaranya :

\begin{tabular}{cccll}
\hline No & \multicolumn{2}{c}{ Peneliti } & \multicolumn{1}{c}{ Judul Penelitian } & \multicolumn{1}{c}{ Hasil } \\
\hline 1 & Trismi & Ristyowati & Minimasi Waste Pada Aktivitas Proses & Pemborosan terjadi \\
& $(2017)$ & Produksi Dengan Konsep Lean di lantai produksi & Manufacturing (Studi Kasus di PT. Sport dalam bentuk cacat \\
& & Glove Indonesia). & (defect) terjadi pada \\
& & & proses jahit dengan \\
& & & prosentase 76,8\% \\
& & & dari total jumlah \\
& & & cacat.
\end{tabular}




\begin{tabular}{|c|c|c|c|}
\hline No & Peneliti & Judul Penelitian & Hasil \\
\hline 2 & $\begin{array}{ll}\text { Wahyu } & \text { Adrianto } \\
(2015) & \end{array}$ & $\begin{array}{l}\text { Analisis Penerapan Lean Production } \\
\text { Process Untuk Mengurangi Lead Time } \\
\text { Process Perawatan Engine (Studi Kasus } \\
\text { PT.GMF Aerosia). }\end{array}$ & $\begin{array}{l}\begin{array}{l}\text { Bobot } \\
\text { tertinggi }\end{array} \quad \begin{array}{r}\text { yaitu } \\
\text { dengan }\end{array} \\
\text { waiting } \\
\text { bobot sebesar } 0.38, \\
\text { diikuti defect }(0.23) \text {, } \\
\text { unnecessary } \\
\text { inventory (0.15), } \\
\text { excessive } \\
\text { transportation } \\
\text { (0.09), } \\
\text { Inappropriate } \\
\text { processing (0.08). } \\
\text { Unnecessary motion } \\
\text { (0.07). }\end{array}$ \\
\hline 3 & $\begin{array}{l}\text { Novia Alvin Nur } \\
\text { Annisa (2014) }\end{array}$ & $\begin{array}{l}\text { Pendekatan Lean six sigma Untuk } \\
\text { Mengurangi Waste Proses Produksi } \\
\text { Brown Paper (Studi Kasus: PT Kertas } \\
\text { Leces, Kabupaten Probolinggo). }\end{array}$ & $\begin{array}{l}\text { Terdapat } 5 \text { jenis } \\
\text { waste yang terjadi } \\
\text { yakni waste defect, } \\
\text { waiting, inventory, } \\
\text { inappropriate } \\
\text { processing dan } \\
\text { excess } \\
\text { transportation. }\end{array}$ \\
\hline 4 & $\begin{array}{lr}\text { Nailah, } & \text { Ambar } \\
\text { Harsono, } & \text { Gita } \\
\text { Permata } & \text { Liansari } \\
(2014) & \end{array}$ & $\begin{array}{l}\text { Usulan Perbaikan Untuk Mengurangi } \\
\text { Jumlah Cacat pada Produk Sandal Eiger } \\
\text { S-101 Lightspeed dengan Menggunakan } \\
\text { Metode Six sigma }\end{array}$ & $\begin{array}{l}\text { Jenis cacat yang } \\
\text { paling kritis untuk } \\
\text { sandal Eiger S-101 } \\
\text { adalah jenis cacat } \\
\text { spreading glue is } \\
\text { not even. Penyebab- } \\
\text { penyebab cacat yang } \\
\text { ditemukan dilihat } \\
\text { dari faktor operator, } \\
\text { cara pengeleman, } \\
\text { lingkungan kerja, } \\
\text { tidak adanya } \\
\text { pengawasan }\end{array}$ \\
\hline
\end{tabular}

\section{Tahap-tahap six sigma}

Define

Tahap define yang pertama harus dilakukan adalah mengumpulkan data pendukung yang menunjukkan adanya indikasi permasalahan. Kemudian dilakukan langkah- langkah sebagai berikut:

a. Menggambarkan flow proses produksi dan uraian dalam proses produksi, proses pengantongan dan sampai dengan penyimpanan produk di gudang.

b. Mengidentifikasi penyebab defect yang terjadi pada produk.

c. Identifikasi objek amatan penelitian dilakukan dengan metode kuantitatif berupa pengumpulan data dan melakukan brainstorming dengan pihak perusahaan untuk menentukan objek penelitian yang akan diamati, sehingga akan terfokus pada objek kritis yang sangat perlu untuk dilakukan perbaikan kualitas.

\section{Measure}

Tahapan measure dilakukan berdasarkan tahapan define sebelumnya, Setelah diketahui penyebab - penyebab defect yang terjadi pada produk sarung tangan golf maka langkah selanjutnya antara lain: 
a. Identifikasi jenis defect yang paling berpengaruh terhadap kualitas produk dilakukan dengan cara:

- Melakukan brainstorming pada pihak perusahaan untuk mengetahui jenis jenis defect yang paling sering terjadi.

- Menentukan Critical To Quality pada jenis defect setelah jenis- jenis defect diketahui dengan menggunakan diagram pareto untuk mengetahui seberapa besar pengaruh dari defect tersebut.

b. Melakukan pengukuran tingkat sigma dan Defect For Milion Opportunitas dengan mengkonversikan nilai DPMO kedalam tabel sigma.

Tabel 1. Langkah mencari nilai six sigma

\begin{tabular}{lll}
\hline Langkah & \multicolumn{1}{c}{ Tindakan } & \multicolumn{1}{c}{ Persamaan } \\
\hline 1 & Proses apa yang ingin diketahui & - \\
2 & Berapa banyak unit diproduksi & - \\
3 & Berapa banyak produk cacat & Langkah 3 / langkah 4 \\
4 & Hitung tingkat kecacatan & \\
& berdasarkan langkah 3 & Banyaknya karakteristik CTQ \\
5 & Tentukan CTQ penyebab produk cacat & Langkah 4 / langkah 5 \\
6 & Hitung peluang tingkat cacat karakteristik CTQ & Langkah 6 x 1.000.000 \\
7 & Hitung kemungkinan cacat per DPMO & - \\
\hline
\end{tabular}

Perhitungan DPMO dan level sigma bertujuan untuk mengukur kemampuan dan kapabilitas sigma pada saat ini. Adapun nilai- nilai yang diperlukan untuk menghitung nilai DPMO yang perlu diketahui adalah Unit (U) yang menyatakan jumlah produk yang diperiksa dalam inspeksi, selama waktu pengamatan. Defect (D) yang menyatakan jumlah produk cacat yang terjadi selama waktu pengamatan. Opportunity (OP) menyatakan karakteristik yang berpotensi menyebabkan cacat.

Langkah-langkah yang diperlu -kan dalam perhitungan DPMO adalah sebagai berikut:

1) Defect per Unit

$\mathrm{DPU}=\frac{D}{v}$

2) Total Opportunities (TOP)

$\mathrm{TOP}=U \times O P$

3) Defect per Opportunities (DPO)

$\mathrm{DPO}=\frac{D}{T O P}$

4) Defect per Million Opportunities

$D P M O=D P O \times 1.000 .000$

5) Tingkat Sigma

Perhitungan konversi nilai DPMO menjadi nilai sigma dilakukan dengan menggunakan microsoft excel dengan rumus perhitungan :

Konversi Nilai DPMO $=$ NORMSINV $((1.000 .000-$

DPMO)(1.000.000)+1.5) 


\section{Tahap analisa dan perbaikan}

Tahap analisa dan perbaikan merupakan lanjutan dari fase sebelumnya pada metodologi DMAIC. Fase yang digunakan adalah fase analyze dan fase improve.

\section{Analyze}

Melakukan analisa terhadap penyebab jenis defect yang paling berpengaruh untuk mengetahui faktor-faktor penyebab setiap critical variabel menggunakan diagram fishbone yang diidentifikasi dari objek amatan sehingga diketahui faktor - faktor penyebab variabel yang kritis.

\section{Improve}

Tahapan Improve yang dilakukan akan fokus pada penyelesaian permasalahan terkritis yang, memerlukan langkah perbaikan. Berikut adalah penjelasan untuk melakukan tahap improve.

a. Langkah improve yang dilakukan bukan merupakan alternatif pemillihan solusi perbaikan. Tetapi menetapkan 1 usulan perbaikan terpenting yang akan di bahas secara detail dan menyeluruh.

b. Membuat rencana perbaikan terhadap defect.

c. Melakuan pemilihan usulan alternatif tersebut untuk menghilangkan defect.

\section{Control}

Tahapan Control adalah tahapan akhir dalam six sigma dimana dalam tahapan ini dilakukan mekanisme pengendalian untuk menciptakan proses perbaikan berkesinambungan menuju tercapainnya zero defect.

\section{HASIL DAN PEMBAHASAN}

\section{Tahap define}

Tahapan ini merupakan langkah awal yang tujuan utamanya adalah untuk mengidentifikasi permasahalan utama yang menjadi prioritas di dalam perbaikan mutu produk dan proses di perusahaan.

\section{Identifikasi}

Atribut - atribut dari pemborosan (waste) penyebab CTQ kuci pada produk sarung tangan golf dilakukan identifikasi pada saatpengamatan dengan hasil sebagai berikut:

\section{Tabel 2. CTQ}

\begin{tabular}{clcc}
\hline No & Nama Proses & Total Jumlah Cacat & Presentase \\
\hline 1 & Pasang Ibu Jari & 686 & $21,40 \%$ \\
2 & Pasang Machi & 346 & $10,79 \%$ \\
3 & Pasang Velcro & 156 & $4,87 \%$ \\
4 & Variasi SN & 173 & $5,40 \%$ \\
5 & Variasi DN & 97 & $3,03 \%$ \\
6 & Sambung Omo & 63 & $1,97 \%$ \\
7 & Karet Knuckle & 257 & $8,02 \%$ \\
8 & Pasang Pita & 171 & $5,33 \%$ \\
9 & Jahit Logo & 169 & $5,27 \%$ \\
10 & Lipat Omo & 798 & $24,89 \%$ \\
11 & Lipat Ibu Jari & 290 & $9,05 \%$ \\
& Total & 3206 & $100,00 \%$ \\
\hline
\end{tabular}




\section{Overproduction}

Pemborosan yang terjadi karena adanya kelebihan produksi pada produk sarung tangan golf adalah 0 dikarenakan sistem produksi yang digunakan oleh pihak perusahaan adalah make to order.

\section{Defect}

Hasil pemborosan defect selama pengamatan adalah yang paling banyak terjadi pada proses jahit dimana masing-masing CTQ mengalami loncat, miring, kerut, meleset, tidak oval, kotor, adanya sisa benang dan bekas jahitan. Sedangkan pada bagian cutting dan pengeliman, pemborosan defect yang terjadi adalah salah potong dan pengeliman tidak rata.

\section{Unnecessary inventory}

Adapun pemborosan dikarenakan penyimpanan yang tidak perlu pada produksi sarung tangan golf adalah 0 dikarenakan bahan baku yang dugunakan dalam proses produksi disediakan oleh customer atau pemesan.

\section{Inapproriate processing}

Adapun waste aktifitas tidak perlu dalam satu kali proses produksi sarung tangan golf adalah:

- Terburu- buru

- Operator mengabaikan SOP

- Berhenti sejenak karena kelelahan

- Tidak fokus

\section{Waiting}

Adapun pemborosan waktu menunggu yang terjadi diantaranya:

- Menunggu material

- Menunggu rework produk cacat

- Menunggu pengeliman

- Perbedaan tingkat keterampilan pekerja

\section{Unnecessary motion}

Pemborosan berupa gerakan tidak perlu dalam satu kali proses produksi sarung tangan golf diantaranya:

- Menggerakkan bagian tubuh yang lelah

- Terdiam sesaat

- Tidak fokus (mengobrol)

- Mengirim kembali produk cacat untuk rework atau pengerjaan ulang

Data reject yang diperoleh merupakan data produksi dan jumlah cacat produk sarung tangan golf pada bulan juli 2021 dapat dilihat pada tabel berikut:

Tabel 3. Data defect produk

\begin{tabular}{ccc}
\hline $\begin{array}{c}\text { No } \\
\text { Periode }\end{array}$ & $\begin{array}{c}\text { Defect } \\
\text { D }\end{array}$ & $\begin{array}{c}\text { Unit } \\
\text { U }\end{array}$ \\
\hline 1 & 142 & 1613 \\
2 & 198 & 1926 \\
3 & 159 & 1860 \\
4 & 170 & 1405 \\
5 & 158 & 1582 \\
6 & 154 & 1540 \\
7 & 193 & 1564
\end{tabular}




\begin{tabular}{ccc}
\hline $\begin{array}{c}\text { No } \\
\text { Periode }\end{array}$ & $\begin{array}{c}\text { Defect } \\
\text { D }\end{array}$ & $\begin{array}{c}\text { Unit } \\
\text { U }\end{array}$ \\
\hline 8 & 161 & 1558 \\
9 & 174 & 1556 \\
10 & 188 & 1610 \\
11 & 169 & 1903 \\
12 & 137 & 1410 \\
13 & 102 & 1489 \\
14 & 115 & 1435 \\
15 & 132 & 1381 \\
16 & 190 & 1946 \\
17 & 133 & 1935 \\
18 & 175 & 1350 \\
19 & 202 & 2490 \\
20 & 154 & 1995 \\
TOTAL & $\mathbf{3 2 0 6}$ & $\mathbf{3 3 5 4 8}$ \\
\hline
\end{tabular}

Tahap measure

Penentuan Prioritas Permasalahan Pengukuran ini dimaksudkan untuk mengetahui sejauh mana output akhir dari proses dapat memenuhi kebutuhan pelanggan ataupun standar - standar mutu yang ada.

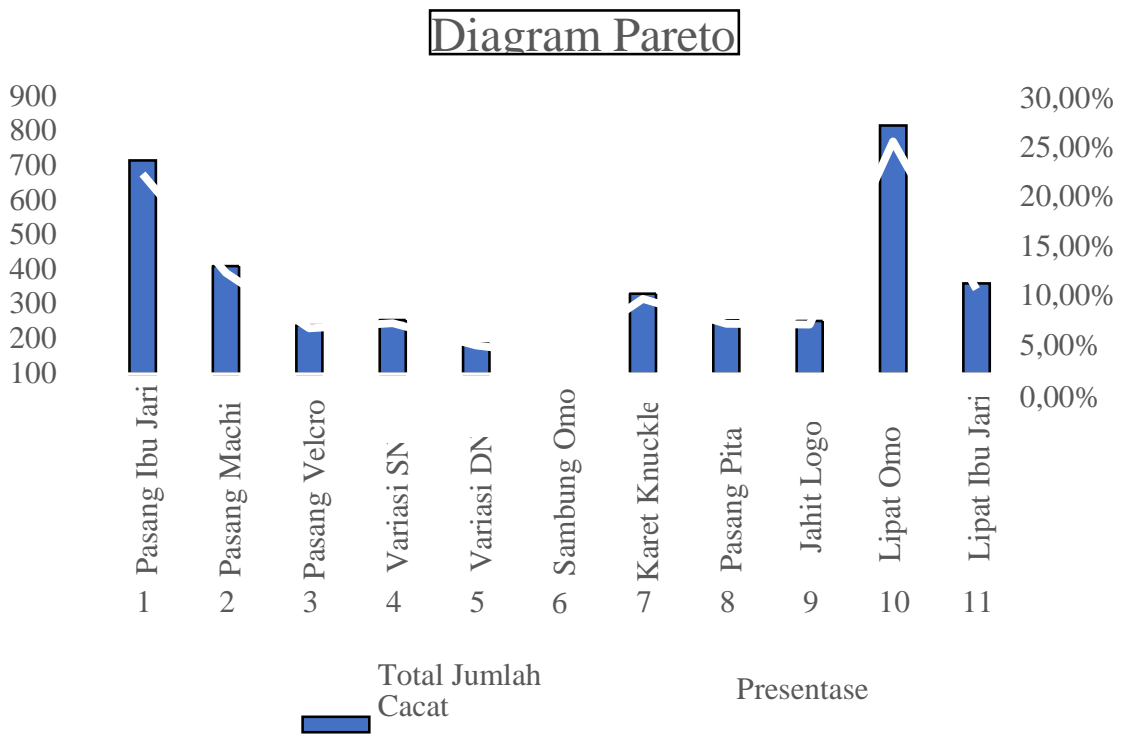

Gambar 1. Diagram pareto kecacatan produk sarung tangan golf

Jika dilakukan pengurutan dan pemilihan jenis reject potensial yang dominan menyebabkan tingginya kecacatan pada produksi sarung tangan golf ialah:

1. Lipat Omo (body)

2. Pasang Ibu Jari

3. Pasang Machi

4. Lipat Ibu Jari

5. Karet Knuckle 


\section{Pengukuran baseline kinerja}

Tabel 4. Hasil perhitungan DPMO dan level sigma produk sarung tangan golf

\begin{tabular}{crrrrrrrr}
\hline $\begin{array}{c}\text { No } \\
\text { Periode }\end{array}$ & Defect & Unit & Opt & Total Opt & DPU & DPO & DPMO & \multicolumn{1}{c}{ SIGMA } \\
\hline 1 & 142 & 1613 & 11 & 17743 & 0,088035 & 0,008003 & 8003,156 & 3,908772 \\
2 & 198 & 1926 & 11 & 21186 & 0,102804 & 0,009346 & 9345,794 & 3,851625 \\
3 & 159 & 1860 & 11 & 20460 & 0,085484 & 0,007771 & 7771,261 & 3,919485 \\
4 & 170 & 1405 & 11 & 15455 & 0,120996 & 0,011 & 10999,68 & 3,790379 \\
5 & 158 & 1582 & 11 & 17402 & 0,099874 & 0,009079 & 9079,416 & 3,862363 \\
6 & 154 & 1540 & 11 & 16940 & 0,1 & 0,009091 & 9090,909 & 3,861894 \\
7 & 193 & 1564 & 11 & 17204 & 0,123402 & 0,011218 & 11218,32 & 3,782893 \\
8 & 161 & 1558 & 11 & 17138 & 0,103338 & 0,009394 & 9394,328 & 3,849698 \\
9 & 174 & 1556 & 11 & 17116 & 0,111825 & 0,010166 & 10165,93 & 3,820167 \\
10 & 188 & 1610 & 11 & 17710 & 0,11677 & 0,010615 & 10615,47 & 3,803852 \\
11 & 169 & 1903 & 11 & 20933 & 0,088807 & 0,008073 & 8073,377 & 3,905581 \\
12 & 137 & 1410 & 11 & 15510 & 0,097163 & 0,008833 & 8833,011 & 3,872545 \\
13 & 102 & 1489 & 11 & 16379 & 0,068502 & 0,006227 & 6227,486 & 3,998985 \\
14 & 115 & 1435 & 11 & 15785 & 0,080139 & 0,007285 & 7285,398 & 3,942875 \\
15 & 132 & 1381 & 11 & 15191 & 0,095583 & 0,008689 & 8689,356 & 3,878596 \\
16 & 190 & 1946 & 11 & 21406 & 0,097636 & 0,008876 & 8876,016 & 3,87075 \\
17 & 133 & 1935 & 11 & 21285 & 0,068734 & 0,006249 & 6248,532 & 3,997789 \\
18 & 175 & 1350 & 11 & 14850 & 0,12963 & 0,011785 & 11784,51 & 3,764083 \\
19 & 202 & 2490 & 11 & 27390 & 0,081124 & 0,007375 & 7374,954 & 3,938462 \\
20 & 154 & 1995 & 11 & 21945 & 0,077193 & 0,007018 & 7017,544 & 3,956364 \\
TOTAL & 3206 & 33548 & 11 & 369028 & 0,095565 & 0,008688 & 8687,688 & 3,878667 \\
\hline
\end{tabular}

Berdasarkan perhitungan di atas, dari 33.548-unit produk yang diperiksa selama periode pengamatan, ditemukan sebanyak 3.206-unit produk mengalami kecacatan. Sehingga dengan tingkat kecacatan yang ada berdasarkan 11 jenis kecacatan (CTQ), maka diperoleh nilai DPMO sebesar 0,008688. Artinya dari 1.000 .000 produk yang dihasilkan selama proses, dapat terjadi kecacatan sebanyak 8.688-unit produk. Dengan menggunakan tabel konversi sigma diperoleh level sigma sebesar 3,88.

\section{Tahap analyze}

\section{Analisis tingkat kestabilan proses}

Analisis tingkat kestabilan proses ini ditujukan untuk mengetahui apakah kecacatan produk selama proses berada dalam keadaan dapat dikendalikan atau tidak.

Tabel 5. Data kecacatan pada produk sarung tangan golf

\begin{tabular}{ccccccc}
\hline No & Unit & Defect & $\begin{array}{c}\text { Proporsi } \\
\text { Defect }\end{array}$ & CL & UCL & LCL \\
\hline 1 & 1613 & 142 & 0,088034718 & 0,095564564 & 0,117525017 & 0,073604111 \\
2 & 1926 & 198 & 0,102803738 & 0,095564564 & 0,115661523 & 0,075467606 \\
3 & 1860 & 159 & 0,085483871 & 0,095564564 & 0,116014974 & 0,075114155 \\
4 & 1405 & 170 & 0,120996441 & 0,095564564 & 0,119094477 & 0,072034651 \\
5 & 1582 & 158 & 0,099873578 & 0,095564564 & 0,117739136 & 0,073389992 \\
6 & 1540 & 154 & 0,1 & 0,095564564 & 0,118039482 & 0,073089646
\end{tabular}




\begin{tabular}{ccccccc}
\hline No & Unit & Defect & $\begin{array}{c}\text { Proporsi } \\
\text { Defect }\end{array}$ & CL & UCL & LCL \\
\hline 7 & 1564 & 193 & 0,123401535 & 0,095564564 & 0,117866374 & 0,073262754 \\
8 & 1558 & 161 & 0,103337612 & 0,095564564 & 0,117909276 & 0,073219853 \\
9 & 1556 & 174 & 0,111825193 & 0,095564564 & 0,117923632 & 0,073205497 \\
10 & 1610 & 188 & 0,116770186 & 0,095564564 & 0,117545468 & 0,073583661 \\
11 & 1903 & 169 & 0,088807147 & 0,095564564 & 0,115782606 & 0,075346523 \\
12 & 1410 & 137 & 0,097163121 & 0,095564564 & 0,11905272 & 0,072076408 \\
13 & 1489 & 102 & 0,068502351 & 0,095564564 & 0,118421138 & 0,07270799 \\
14 & 1435 & 115 & 0,080139373 & 0,095564564 & 0,118847221 & 0,072281908 \\
15 & 1381 & 132 & 0,095582911 & 0,095564564 & 0,119298056 & 0,071831072 \\
16 & 1946 & 190 & 0,097636177 & 0,095564564 & 0,115557983 & 0,075571145 \\
17 & 1935 & 133 & 0,06873385 & 0,095564564 & 0,115614731 & 0,075514397 \\
18 & 1350 & 175 & 0,12962963 & 0,095564564 & 0,119569005 & 0,071560123 \\
19 & 2490 & 202 & 0,081124498 & 0,095564564 & 0,113239539 & 0,077889589 \\
20 & 1995 & 154 & 0,077192982 & 0,095564564 & 0,115310923 & 0,075818205 \\
& 33548 & 3206 & & & & \\
& $\bar{p}$ & & 0,095564564 & & & \\
\hline
\end{tabular}

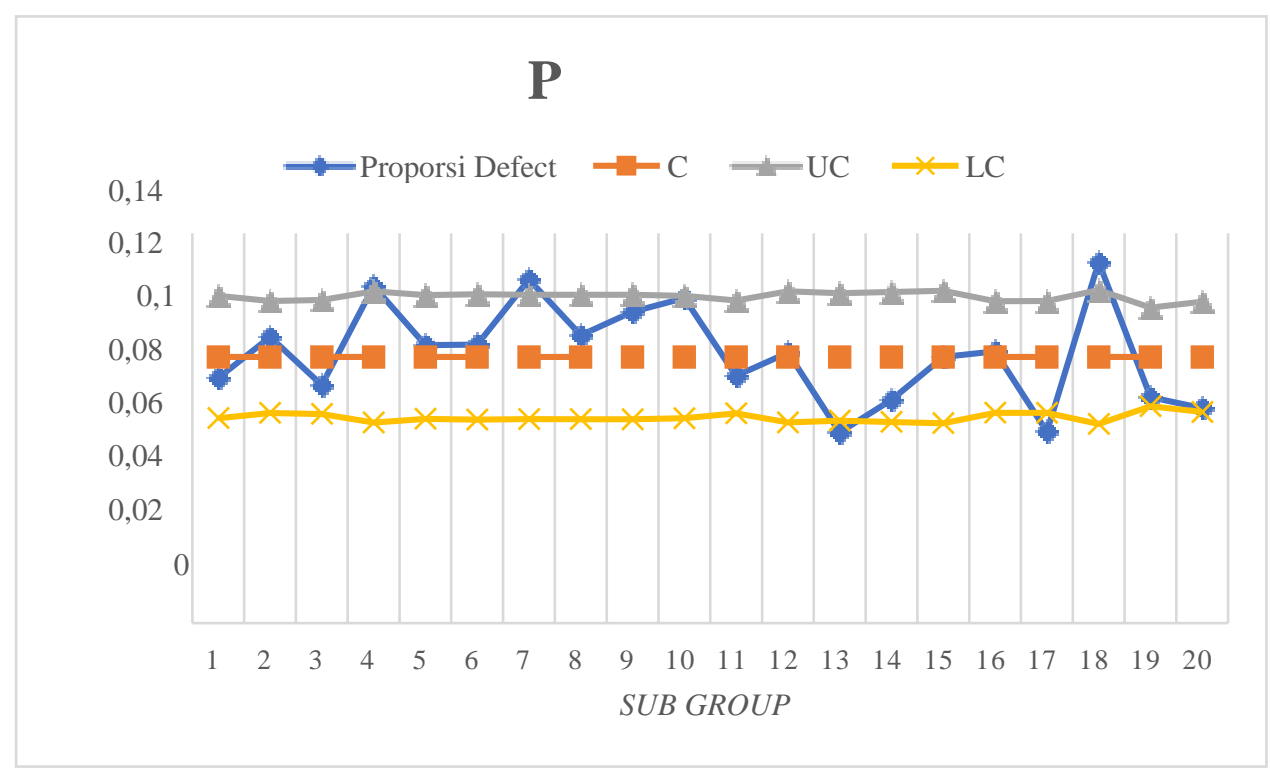

Gambar 2. Peta kendali $\overline{\mathbf{p}}$ sarung tangan golf

Analisis terhadap peta kendali $\bar{p}$ pada produk sarung tangan golf diatas menunjukkan bahwa distribusi kecacatan produk berada diluar batas-batas kendali atas (UCL) yaitu sub group 4, 7, dan 18. Keabnormalan ini terjadi karena sering terjadinya cacat pada produk. 


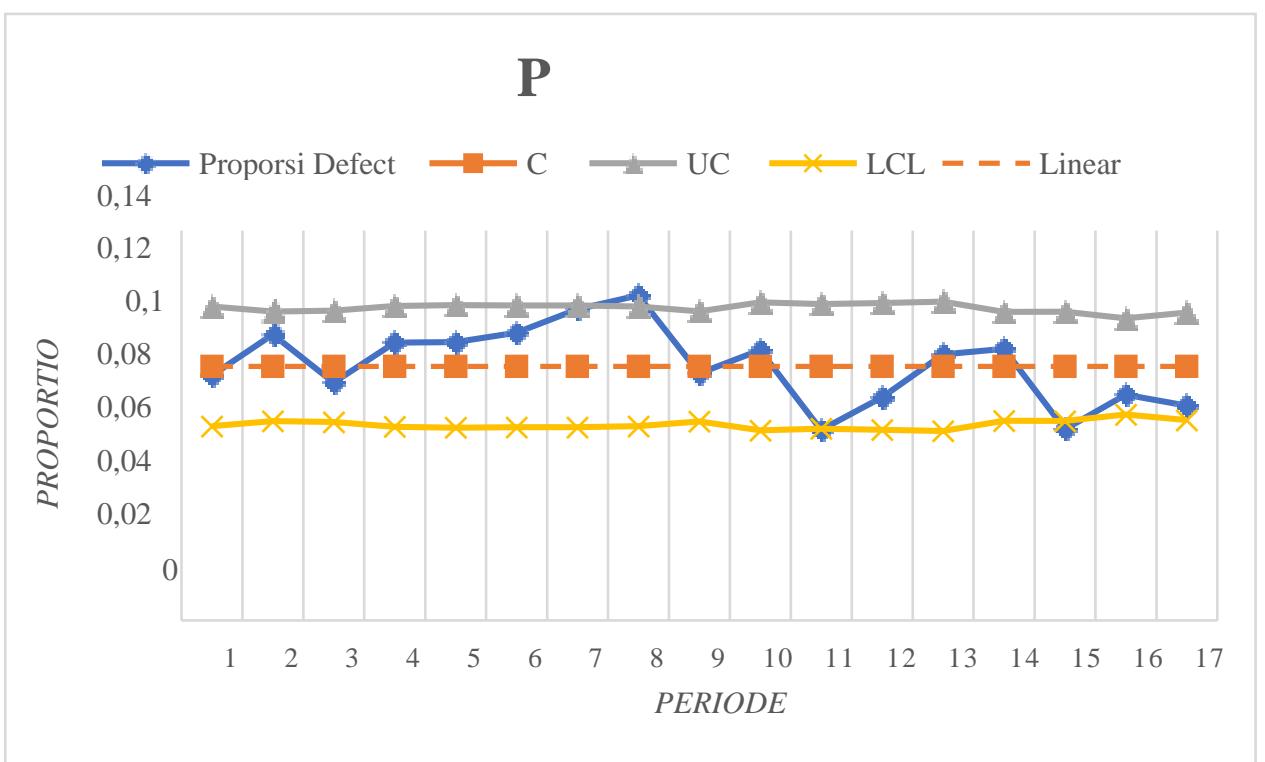

Gambar 3. Peta kendali $\bar{p}$ sarung tangan golf revisi

Adapun perhitungan nilai DPMO dan SQL yang dilakukan adalah sebagai berikut:

a. Perhitungan nilai DPO (Defect per Opportunity) :

$\mathrm{DPO}=\frac{\text { Banyak cacat Yang Diperoleh }}{\text { Banyak Hasil Produksi x CTQ Potensial }}$

$\mathrm{DPO}=0,00829810991$

b. Perhitungan nilai DPMO (Defect PerMillion Opportunity) :

DPMO $=$ DPO $\times 1.000 .000$

$\mathrm{DPMO}=0,00829810991 \times 1.000 .000$

$=8298$ dikonversikan dengan nilai sigma.

c. Penentuan sigma level

Nilai kapabilitas sigma diproleh melalui tabel konversi DPMO ke nilai sigma, Berdasarkan hasil perhitungan nilai DPMO yaitu 8298 berada pada tingkat sigma 3,9 (hasil ini didapat dari konversi tabel sigma).

Tabel 6. Perhitungan DPMO dan level sigma revisi

\begin{tabular}{|c|c|c|c|}
\hline Langkah & Tindakan & Persamaan & $\begin{array}{c}\text { Hasil } \\
\text { Perhitungan }\end{array}$ \\
\hline 1 & Proses apa yang anda ingin ketahui? & - & $\begin{array}{r}\text { Produksi } \\
\text { Sarung } \\
\text { Tangan Golf }\end{array}$ \\
\hline 2 & $\begin{array}{l}\text { Berapa banyak unit produksi yang diproduksi } \\
\text { ? }\end{array}$ & - & 29229 \\
\hline 3 & Berapa banyak unit produk yang gagal? & - & 2668 \\
\hline 4 & $\begin{array}{l}\text { Hitung tingkat cacat (kesalahan) berdasarkan } \\
\text { pada langkah } 3\end{array}$ & $\begin{array}{l}\text { (langkah } \\
\text { 3)/ } \\
\text { (langkah 2) }\end{array}$ & 0,091279209 \\
\hline 5 & $\begin{array}{l}\text { Tentukan banyaknya CTQ potensial yang } \\
\text { dapat mengakibatkan cacat (kesalahan) }\end{array}$ & Jumlah CTQ & 11 \\
\hline
\end{tabular}




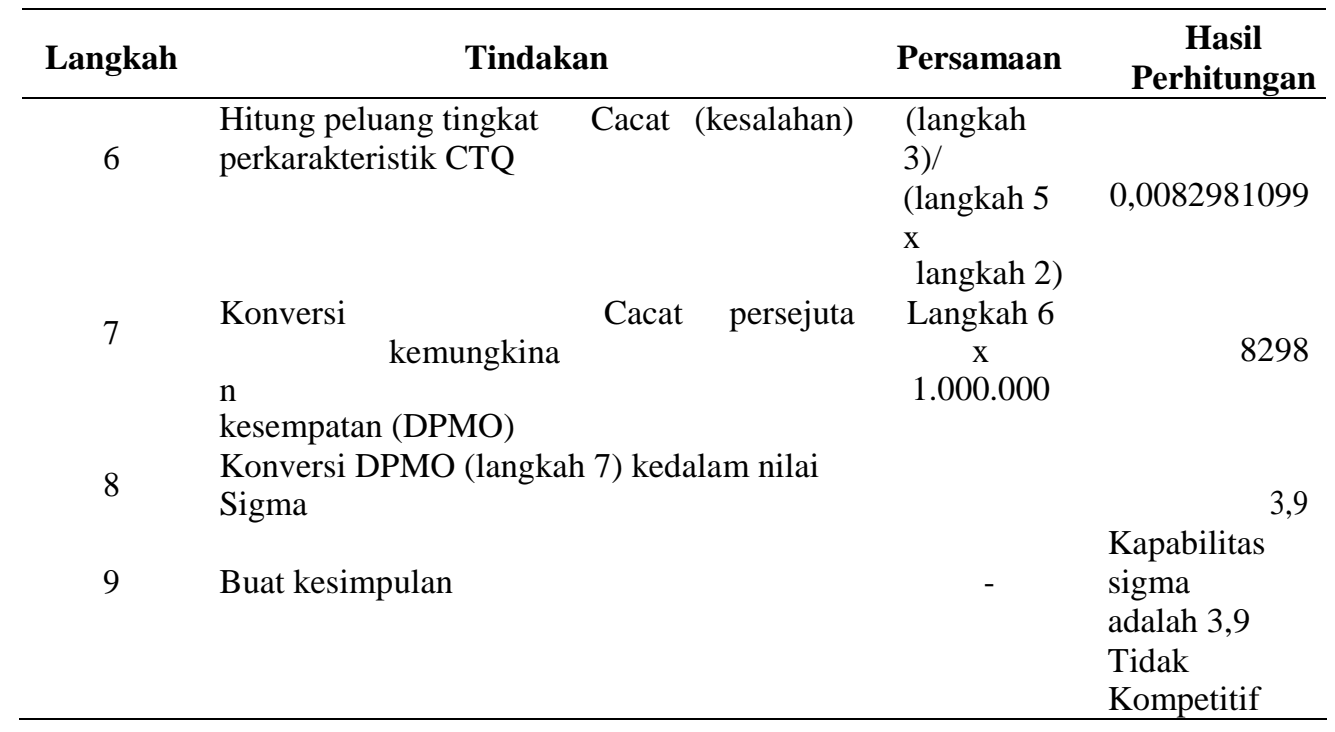

\section{Analisis penyebab kecacatan}

Penggambaran permasalahan melalui penyusunan diagram sebab akibat dapat mempermudah perusahaan dalam mengelompokkan penyebab serta solusi - solusi perbaikan yang dapat dilaksanakan untuk setiap penyebab permasalahan dijelaskan dengan diagram fishbone berikut:

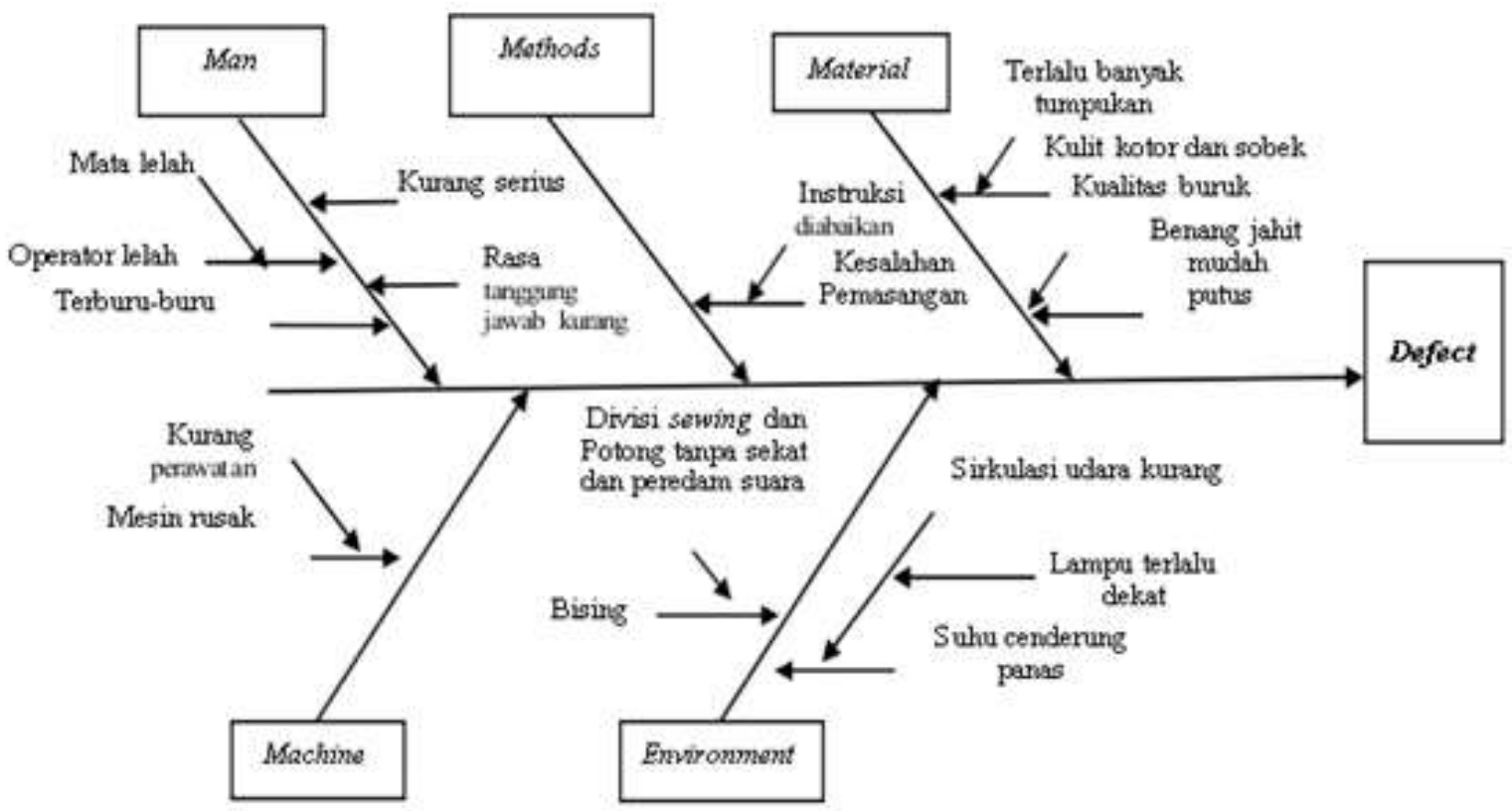

Gambar 4. Diagram fishbone penyebab kecacatan pada produk

\section{Tahap improve}

\section{Penyusunan langkah perbaikan}

Sebagai langkah perbaikan terhadap penyebab terjadinya kerusakan, dapat dilakukan dengan menyusun daftar berupa tabel 5W1H yang terdiri dari What, Why, When, Who, Where dan How. Untuk setiap jenis kecacatan memerlukan perlakuan yang berbeda agar penanggulangan kecacatan produksi lebih fokus dan terarah. 


\section{Tahap control}

\section{Mekanisme pengendalian}

Dalam upaya meraih tingkat pencapaian kualitas tertinggi melalui upaya- upaya penekanan terhadap faktor- faktor yang dapat menimbulkan kecacatan produk maupun kesalahankesalahan selama proses produksi. Untuk itu, beberapa usulan yang dapat diterapkan sebagai mekanisme pengendalian terhadap berbagai proses yang dapat menimbulkan kecacatan dan keselahan prosedur tersebut dapat diuraikan ke dalam tabel sebagai berikut:

Tabel 7. Mekanisme pengendalian

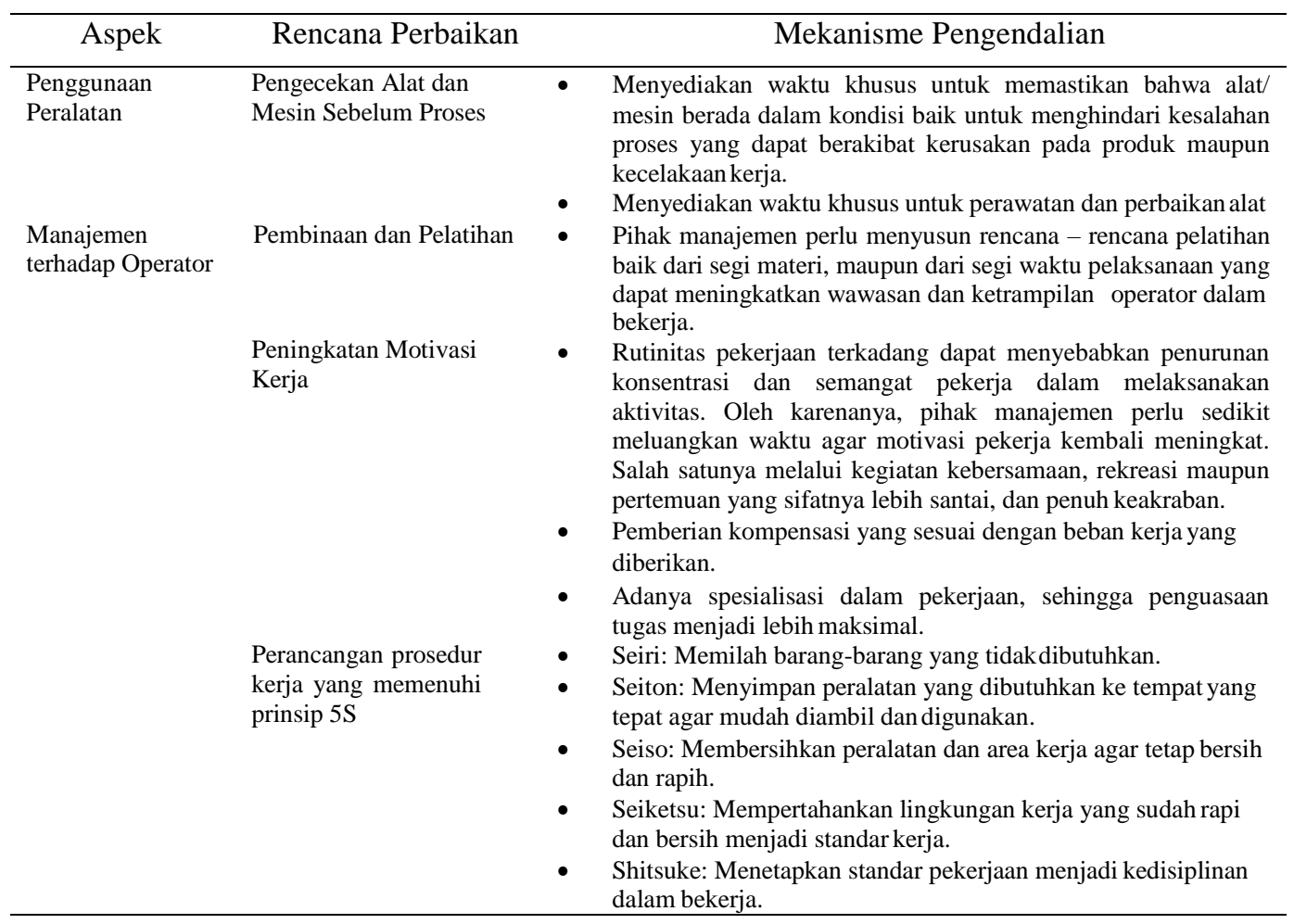

\section{SIMPULAN}

Berdasarkan hasil analisis dan pembahasan untuk mengurangi defect pada produk sarung tangan golf pada CV. Cipta Manunggal didapatkan hasil sebagai berikut:

a. Setelah dilakukan pengurutan dan pemilihan jenis kegagalan potensial yang dominan pada produksi sarung tangan golf adalah:

Lipat Omo (body), Pasang Ibu Jari, Pasang Machi, Lipat Ibu Jari, Karet Knuckle.

b. Upaya yang dilakukan untuk mengurangi tingkat terjadinya kecacatan yaitu sebagai berikut:

- Toleransi kepada pekerja untuk penyegaran tubuh

- Pengawasan diperketat

- Arahan, bimbingan dan pelatihan

- Pemilihan bahan baku yang berkualitas dan tepat

- Evaluasi tata letak pabrik

SOP yang ditentukan.

Penyediaan tempat yang bersih dan cukup luas untuk menyimpan bahan baku, menentukan tumpukan max bahan baku. 
$>$ Operator bekerja secara efektif dan efisien sehingga dapat menghemat tenaga dan waktu.

Sebaiknya menggunakan ear plug untuk menghindari kebisingan mesin.

$>$ Memperhatikan layout fasilitas, menambah ventilasi udara / blower.

\section{DAFTAR PUSTAKA}

Al Fakhri, F. 2010. Analisis Pengendalian Kualitas Produksi Di PT. Masscom Grahpy Dalam Upaya Mengendalikan Tingkat Kerusakan Produk Menggunakan Alat Bantu Statistik. Ekonomi Universitas Diponegoro, Semarang.

Alkatiri, H.A. Adrianto, H. dan Novirani, D. 2015. Implementasi Pengendalian Kualitas Untuk Mengurangi Jumlah Produk Cacat Tekstil Kain Katun Menggunakan Metode Six sigma Pada PT. SSP. Jurnal Teknik Industri Itenas. 3 (3). 148 - 159.

Andrianto, W. dan M. Kholil, 2015. Analisis Penerapan Lean Production Process Untuk Mengurangi Lead Time Process Perawatan Engine (STUDI KASUS PT.GMF AEROASIA). Jurnal Optimasi Sistem Industri, Vol. 14 No. 2, Oktober 2015:299-309

Annisa, N.A.N. Sugiono. dan Tantrika, C.F.M. 2014. Pendekatan Lean six sigma Untuk Mengurangi Waste Proses Produksi Brown Paper (Studi Kasus: PT Kertas Leces, Kabupaten Probolinggo). Jurusan Teknik Industri Universitas Brawijaya. 406 - 417.

Gaspersz, V. (2017). Lean six sigma For Manudafturing and Service Industries. Jakarta: Gramedia Pustaka Utama.

Gaspersz, Vincent, 2016, Continuous Cost Reduction Through Lean Sigma Approach. Jakarta: Gramedia Pustaka Utama.

Gasperz, Vincent. 2014. Pedoman Implementasi Program Six sigma. Jakarta: Gramedia Pustaka Utama.

Gryna, Frank M. (]2011.Quality Planning and Analysis. McGraw Hill Inc., New York.

http://www.pelajaran.co.id/2017/16/pengertian-produk-jenis-klasifikasi-dan- tingkatanproduk.html. Diakses tanggal 2 September 2018.

https://anzdoc.com/search/Lean\%20Six\%20Sigma\%20-\%20DMAIC/2. Diakses tanggal 12 Agustus 2018

I Made, H. W., 2011. Faktor-Faktor yang Mempengaruhi Produktivitas Kerja Karyawan pada Como Shambala Estate at Begawan Giri Ubud Bali. Jurnal Perhotelan dan Pariwisata, Vol.1 No.1, Agustus 2011.

Lestari D. P, 2010, “Pengendalian Kualitas Produksi Benan Polyester Cotton”, PT Panca Bintang Tunggal Sejahtera, Universitas Sebelas Maret, Surakarta. http://eprints.uns.ac.id/3913/1/166600209201009431.pdf. di akses pada tanggal 07 Agustus 2015. 
M. Poppendieck, “The Principles of Lean Thinking,” ITC, Winnipeg, 2012, pp. 1- 7.

Nailah, Harsono, A. dan Liansari, G.A. 2014. Usulan Perbaikan Untuk Mengurangi Jumlah Cacat pada Produk Sandal Eiger S-101 Lightspeed dengan Menggunakan Metode Six sigma. Jurnal Online Institut Teknologi Nasional. 2 (2). 256 - 267.

Nasution, M. N.. 2015. Manajemen Mutu Terpadu. Bogor: Ghalia Indonesia Pande, Peter S. (2012). The Six sigma Way. ANDI. Yogyakarta.

Pyzdek,T. and P. Keller, 2013, The Hanbook For Quality Management A Complete Guide For Operational Excellent, McGraww-Hill, New York.

Ristyowati, T. Muhsin, A. dan Nurani, P. P. 2017. Minimasi Waste Pada Aktivitas Proses Produksi Dengan Konsep Lean Manufacturing (Studi Kasus di PT. Sport Glove Indonesia). Jurnal OPSI. 10 (1). 85 - 96.

Sepsarianto, Rizky. 2013. Analisis Masalah 7 Tools. URL: http://www.scribd.com/doc/189322119/Analisis-Masalah-7-Tools. Diakses tanggal 2 Agustus 2018.

Suseno dan Sawaludin, 2013. Analisa Produksi Pada Mesin Speed Untuk Mengurangi Cacat Produk. Yogyakarta: Industri Sandang Nusantara ,Universitas Teknologi Yogyakarta. http://jurnalteknik.janabadra.ac.id/wp-content/uploads/2014/03/06-UTYREVISI-SUSENO.pdf. di akses pada tanggal 20 September 2015.

Yusrizal. B, Noviyarsi, dan Yuliza. D. 2012. Peningkatan kualitas produk dengan Quality Function Deployment $(Q F D)$ di Industri Sepatu di Kota Padang. Jurnal Teknik Industri. 1 (2): 195 - 205. 